Pesq. Vet. Bras. 30(1):10-12, janeiro 2010

\title{
Fireweed (Senecio madagascariensis) poisoning in cattle ${ }^{1}$
}

\author{
Cláudio E.F. Cruz ${ }^{2 *}$, Fernando C. Karam ${ }^{3}$, André C. Dalto ${ }^{2}$, Saulo P. Pavarini² \\ Paulo Mota Bandarra ${ }^{2}$ and David Driemeier ${ }^{2}$

\begin{abstract}
Cruz C.E.F., Karam F.C., Dalto A.C., Pavarini S.P., Bandarra P.M. \& Driemeier D. 2010. Fireweed (Senecio madagascariensis) poisoning in cattle. Pesquisa Veterinária Brasileira 30(1):10-12. Departmento de Patologia Clínica Veterinária, Faculdade de Veterinária, Universidade Federal do Rio Grande do Sul, Avenida Bento Gonçalves 9090, Porto Alegre, RS 91540-000, Brazil. E-mail: vetcruz@terra.com.br

In a dairy cattle herd in southern Brazil, 7 out of 554 cattle were affected and died due to Senecio madagascariensis poisoning. Clinical, pathological, and epidemiological findings in the affected cattle were indistinguishable from those usually seen in poisoning caused by other Senecio species. The plant invaded extensive areas in heavily stocked paddocks. Senecio madagascariensis had been spreading in this farm for the last three years, with no control strategy, because neither the farmers nor the local veterinarian knew about the potential risks of this Sernecio species.
\end{abstract}

INDEX TERMS: Poisonous plants, fireweed, Senecio madagascariensis, Asteraceae, plant poisoning, cattle.

RESUMO.- [Intoxicação natural por Senecio madagascariensis (Asteraceae) em bovinos.] Em um rebanho bovino leiteiro no Rio Grande do Sul, sete de 554 bovinos foram afetados e morreram devido à intoxicação por Senecio madagascariensis. Aspectos clínicos, patológicos e epidemiológicos observados nos bovinos afetados foram indistinguíveis daqueles usualmente observados em casos de intoxicações por outras espécies de Senecio. A planta invadiu extensas áreas em potreiros mantidos constantemente com altas lotações de bovinos. Senecio madagascariensis esteve se estabelecendo nesta propriedade pelos últimos três anos, sem que qualquer medida de controle fosse adotada pela equipe técnica do estabelecimento, que desconhecia o potencial tóxico dessa espécie de Senecio.

TERMOS DE INDEXAÇÃO: Plantas tóxicas, Senecio madagascariensis, Asteraceae, intoxicação por planta, bovinos.

\section{INTRODUCTION}

There are about 1,200 worldwide species of Senecio, of which nearly 25 have been demonstrated as toxic to livestock

\footnotetext{
${ }^{1}$ Received on July 28, 2009.

Accepted for publication on August 18, 2009.

2 Departamento de Patologia Clínica Veterinária, Faculdade de Veterinária, Universidade Federal do Rio Grande do Sul (UFRGS), Av. Bento Gonçalves 9090, Porto Alegre, RS 91540-000, Brazil. *Corresponding author: vetcruz@terra.com.br

3 Instituto de Pesquisas Veterinárias Desidério Finamor (IPVDF), Estrada Municipal do Conde 6000, Eldorado do Sul, RS 92990-000, Brazil.
}

(Tokarnia et al. 2000). Although Senecio brasiliensis is the most frequent cause of the Brazilian outbreaks of pyrrolizidine alkaloid poisoning in cattle, S. heterotrichius, S. cisplatinus, S. selloi, and $S$. oxyphyllus have also been occasionally linked to the disease (Barros et al. 1987, Tokarnia et al. 2000). Clinical, pathological, and epidemiological features associated with poisoning by different Senecio species are usually quite similar, if not identical (Tokarnia et al. 2000). Fireweed or Madagascar ragwort (Senecio madagascariensis), a species native to southern Africa (Scott et al. 1998), has been naturalized after accidental introduction in Australia (Parsons \& Cuthbertson 2001), Hawaii (Roux et al. 2006), and Argentina (Villalba \& Fernández 2005), among other countries. S. madagascariensis has just been reported as undergoing a naturalization process in Rio Grande do Sul, southern Brazil (Matzenbacher \& Schneider 2008). Such biotic invasions are expected consequences of the expanding transport and commerce networks in association with a number of other factors; this subject has been properly detailed elsewhere (Mack et al. 2002). Although fireweed has been indicated as toxic to herbivores (Starr et al. 2003, Borrowdale 2004, Allan et al. 2005, Villalba \& Fernández 2005) and demonstrated as containing pyrrolizidine alkaloids (Gardner et al. 2006), outbreaks of poisoning by this plant in animals have rarely been reported. In Hunter River Valley, Australia, fireweed was implicated in a single outbreak involving illthrift and death of 10 sheep (Seaman 1987). This communication describes an outbreak of Senecio madagascariensis poisoning in dairy cattle in Brazil. 


\section{MATERIALS AND METHODS}

Clinical signs and epidemiological data were observed by the authors and retrieved from the farm personnel. Specimens from several organs were collected during necropsies of seven cattle affected by the toxicosis and prepared for histology by standard methods.

\section{RESULTS}

The disease occurred in a dairy farm located in Rio Grande do Sul, southern Brazil. Total cattle herd comprised 554 cattle, mainly Holsteins, but also some Jerseys. Nutritional management in this farm has mainly been achieved through semi-extensive grazing on mixed ryegrass, oat, and clover pastures; however, corn silage, concentrates, and mineral mix have also been part of the diet. Some paddocks located in the surrounding vicinities of the management center had been managed under continuous and heavy stocking. These paddocks have been used to manage especially pre-calving cows, dryingoff cows, and heifers being artificially inseminated. These particular areas have been significantly invaded by Senecio madagascariensis (Fig.1) for the last three years. Contrary to other local well-known toxic weeds (Baccharis megapotamica and Senecio brasiliensis), against which continuous and systematic control strategies had been kept in place for the last 10 years, fireweed was not controlled in this farm because it was neither known as a Senecio species, nor considered toxic to cattle. From February to July, 2008, four pregnant heifers and three (two open) dry cows became ill and died from a disease clinically characterized by apathy, weakness, intermittent diarrhea, abdominal straining, dry coat, progressive emaciation, aimless walking, and death. All of them had been kept on infested fireweed areas for varying periods of time. At necropsy, main findings included small tan liver with numerous well-circumscribed multifocal $2-6 \mathrm{~mm}$ nodules

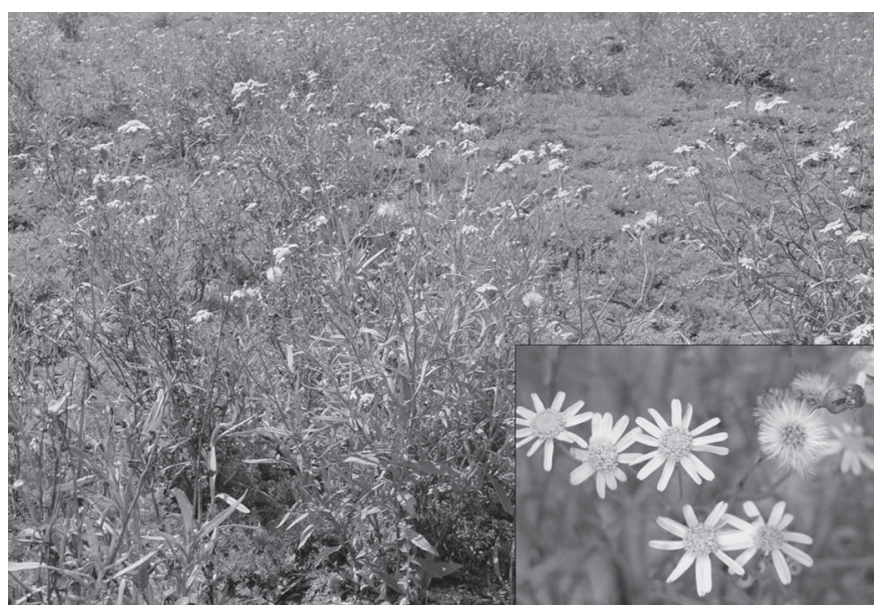

Fig.1. (A) Pre-calving area infested by fireweed (Senecio madagascariensis). Note also the invasion by the low, matforming Bindi weed (Soliva sp.). (B) Insert shows the yellow, daisy-like flowers (usually with 13 petals) and the white, slender, and light seeds of $S$. madagascariensis.

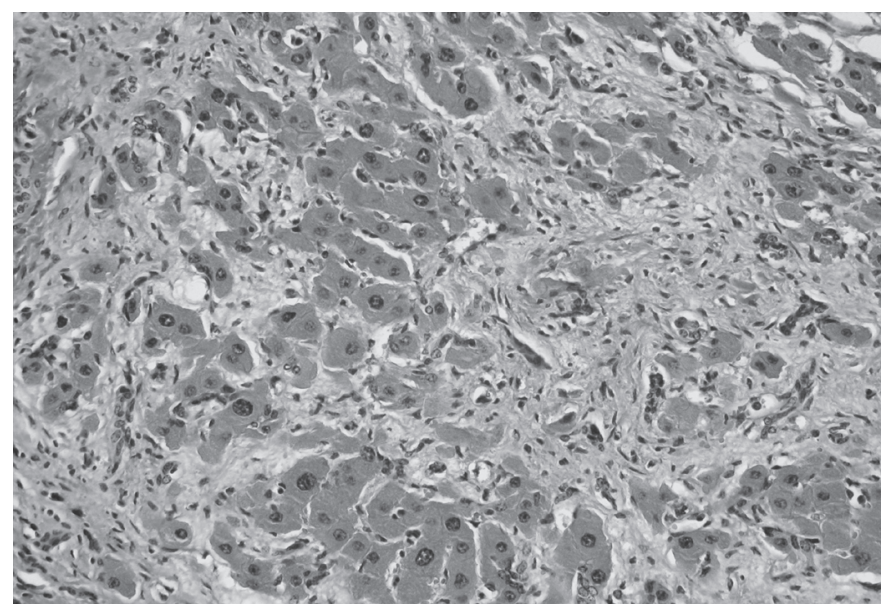

Fig.2. Hepatic parenchyma (cow died by Senecio madagascariensis poisoning). Extensive fibrosis, magalocytosis, and bile duct hyperplasia. HE, 200x.

randomly scattered throughout the hepatic parenchyma. Marked distension of the gallbladder which contained large amounts of dark green bile, edema of the mesentery, and cavitary effusions (hydropericardium and ascites) were also observed. The main histopathological findings included hepatic periportal fibrosis, hepatomegalocytosis, and bile duct hyperplasia (Fig.2).

\section{DISCUSSION}

Although obviously suggested by the pathological findings observed in the first affected cow, the suspicion of Senecio poisoning could not be supported by the initial epidemiological investigations, since Senecio brasiliensis was almost completely absent in the farm. Moreover, seneciosis had never been diagnosed in this herd, even when Senecio brasiliensis was abundant on the farm, about eleven years ago. Further losses motivated a new search for a pyrrolizidine alkaloid source in the farm, when samples of Senecio madagascariensis were collected and subsequently identified (Matzenbacher \& Schneider 2008). Senecio brasiliensis, popularly know as "maria-mole", is the most important toxic plant in southern Brazil (Barros et al. 1987, Karam et al. 2004, Rissi et al. 2007), where it has caused significant economic losses to the cattle industry (Riet-Correa \& Medeiros 2001). While other Senecio species have been linked to seneciosis, to date, spontaneous intoxications due to Senecio madagascariensis in cattle have not been reported in Brazil. As other Senecio species, fireweed is particularly abundant in disturbed areas (Parsons \& Cuthbertson 2001, Borrowdale 2004, Allan et al. 2005), and improper farming practices such as overstocking in association with extensive areas without ground cover vegetation were present in some paddocks. Under such conditions, Senecio madagascariensis is invasive and becomes particularly numerous (Parsons \& Cuthbertson 2001) and livestock may be forced to eat these somewhat unpalatable herbs, especially during scarcity of green pastures. The total herd on this farm has generally been well nourished and 
managed. However, the increase in herd size associated with the lack of simultaneous adaptation of the physical structure in the farm (size and number of paddocks) may have contributed to disturb these areas. While the farmer noticed that the plant had been thriving in the farm for the last three years, large amounts of fireweed could be observed in some pastures, but the species has been reported to be able to disseminate fast (Parsons \& Cuthbertson 2001, Allan et al. 2005). The hepatic changes present in chronic seneciosis may resemble those seen in chronic aflatoxicosis (Humphreys 1988). Evidence against aflatoxin involvement included the absence of a source of toxin, since most (5) affected animals had only been feeding on pastures. The lack of other Senecio species, the characteristic features of pyrrolizidine alkaloid poisoning, and the extensive areas invaded by the potentially toxic fireweed (Gardner et al. 2006) were the main findings supporting this diagnosis. This communication warns field veterinarians about an additional cause of seneciosis.

Aknowledgements.- This study was funded by the Coordenação de Aperfeiçoamento de Pessoal de Nível Superior (CAPES) and Conselho Nacional de Desenvolvimento Científico e Tecnológico (CNPq), Brazil. Authors are grateful to Dr. Nelson I. Matzenbacher for the identification of Senecio madagascariensis.

\section{REFERENCES}

Allan H., Lauders T. \& Walker K. 2005. Fireweed. NWS DPI Primefact 126, The State of New South Wales. (Electronic edition)

Barros C.S.L., Metzdorf L.L. \& Peixoto P.V. 1987. Ocorrência de surtos da intoxicação por Senecio spp. (Compositae) em bovinos no Rio Grande do Sul. Pesq. Vet. Bras. 7:101-107.

Borrowdale I. 2004. Fighting fireweed. Good Life 1:10.

Gardner D.R., Throne M.S., Molyneaux R.J., Foster J.A. \& Seawright A.A. 2006. Pyrrolizidine alkaloids in Senecio madagascariensis from Australia and Hawaii and assessment of possible livestock poisoning. Biochem. Syst. Ecol. 34:736-744.
Humphreys D.J. 1988. Mycotoxins, p.283-291. In: Ibid. (Ed.), Veterinary Toxicology. $3^{\text {rd }}$ ed. Ballliere Tindall, London.

Karam F.S.C., Soares M.P., Haraguchi M., Riet-Correa F., Méndez M.C. \& Jarenkow J.A. 2004. Aspectos epidemiológicos da seneciose na região sul do Rio Grande do Sul. Pesq. Vet. Bras. 24:191-198.

Mack R.N., Simberloff D., Londsdale W.M., Evans H., Clout M. \& Bazzaz F. 2002. Biotic invasions: Causes, epidemiology, global consequences and control. Ecol. Appl. 10:689-710.

Matzenbacher N.I. \& Schneider A.A. 2008. Nota sobre a presença de uma espécie adventícia de Senecio (Asteraceae) no Rio Grande do Sul, Brasil. Revta Bras. Biociênc. 6:111-115.

Parsons W.T. \& Cuthbertson E.G. 2001. Fireweed, Senecio madagascariensis Poir., p.304-305. In: Ibid. (Eds), Noxious Weeds of Australia. $2^{\text {nd }}$ ed. CSIRO Publishing, Collingwood, Vic., Australia.

Riet-Correa F. \& Medeiros R.M.T. 2001. Intoxicações por plantas em ruminantes no Brasil e no Uruguai: importância econômica, controle e riscos para a saúde pública. Pesq. Vet. Bras. 21:120-122.

Rissi D.R., Rech R.R., Pierezan F., Gabriel A.L., Trost M.E., Brum J.S., Kommers G.C. \& Barros C.S.L. 2007. Intoxicações por plantas e micotoxinas associadas a plantas em bovinos no Rio Grande do Sul: 461 casos. Pesq. Vet. Bras. 27:261-268.

Roux J., Wieczorek A.M., Ramadan M.M. \& Tran C.T. 2006. Resolving the native provenance of invasive fireweed (Senecio madagascariensis Poir.) in the Hawaiian Islands as inferred from phylogenetic analysis. Div. Distrib. 12:694-702.

Seaman J.T. 1987. Pyrrolizidine alkaloid poisoning of sheep in New South Wales. Aust. Vet. J. 64:164-167.

Scott L.J., Congdon C. \& Playford J. 1998. Molecular evidence that fireweed (Senecio madagascariensis, Asteraceae) is of South African origin. Plant Syst. Evol. 213:251-257.

Starr F., Starr K. \& Loope L. 2003. Senecio madagascariensis-Fireweed (Asteraceae). United States Geological Survey, Biological Resources Division. Haleakala Field Station, Maui, Hawaii. (Electronic edition)

Tokarnia C.H., Döbereiner J. \& Peixoto P.V. 2000. Plantas Tóxicas do Brasil. Helianthus, Rio de Janeiro, p.98-109.

Villalba J. \& Fernández G. 2005. Otra flor amarilla peligrosa: Senecio madagascariensis. Tambo 150:46-48. 